Rev. Latinoam. Psicopat. Fund., São Paulo, 20(3), 526-543, set. 2017

http://dx.doi.org/10.1590/1415-4714.2017v20n3p526.8

\title{
Quando a pena é um mal necessário na psicose melancólica*1
}

Romuald Hamon*2

Yohan Trichet*3

O presente artigo questiona a lógica autoterapêtica do delírio melancólico. Os casos clínicos propostos como contribuição ensinam que o psicótico melancólico pode tentar tratar sua culpabilidade delirante a partir da violência que ele se inflige, mas também a partir de condutas heteroagressivas, de delitos e de crimes. Em cada um dos casos, a dupla "autoacusação-autopunição" é operante. Ela permite um equilíbrio do gozo. A tal ponto que podemos defender que a pena, na ambivalência (dor moral e sanção aplicada), é um mal necessário na melancolia.

Palavras-chave: Psicose melancólica, delírio, crime, autoacusação, autopunição

\footnotetext{
*1Tradução de Mila Signorelli (Université Rennes 2, Haute-Bretagne, Rennes, France). *2, 3 Université Rennes 2 Haute-Bretagne (Rennes, France).
} 


\section{ARTIGOS}

Em 1974, Lacan distingue a depressão neurótica — a covardia e falha moral do sujeito neurótico que cedeu sobre seu desejo - da psicose melancólica, que é fruto de uma rejeição do inconsciente (Lacan, 1974, 2001). A dor moral do melancólico, essa "pura cultura de pulsão de morte" (Freud, 1923, 2001, p. 227; tradução livre) é "dor de existir", uma dor "em estado puro" (Lacan, 1963, 1966, p. 777; tradução livre). Os sujeitos que a experimentam sentem-se incapazes de lutar. O profundo sentimento de indignidade faz com que aceitem sofrer. Esse sofrimento é para eles justiça, já que eles consideram merecê-lo, por causa dos erros pelos quais se autoacusam. "Assim, ao mesmo tempo em que se lamentam, eles aceitam e às vezes até desejam os suplícios que devem fazer com que expiem seus crimes, ou a morte que livrará o mundo dos indivíduos inúteis ou malvados que eles acreditam ser" (Séglas, 1895, p. 304; tradução livre). Quando não visam a evicção do palco do mundo que pode libertar a terra do ser abjeto que sentem encarnar, os sujeitos melancólicos podem recorrer a diversas formas de castigos para tentar conjurar sua infâmia; com o risco de que essas expiações, desmesuradas, não resultem ao mesmo tempo em sua destruição. Porém, quando os melancólicos conseguem em suas construções delirantes decretar o próprio motivo de suas culpas e a elas consentirem, essas autopunições podem constituir uma solução autoterapêutica. Defenderemos no presente artigo, com a contribuição da clínica, que a pena na psicose melancólica é, em certos casos, um mal necessário. E se alguns recorrem à justiça para encontrarem a pena, outros são capazes de inventar a solução sob medida que lhes permite, a longo prazo, se assegurar do tratamento da culpabilidade delirante.

Rev. Latinoam. Psicopat. Fund., São Paulo, 20(3), 526-543, set. 2017 


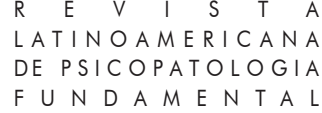

\section{Clínica da melancolia segundo Henri Ey (1954)}

Em seu estudo sobre a melancolia, o psiquiatra francês Henri Ey distingue duas variedades puras da melancolia: a melancolia depressiva, ou melancolia simples, e a melancolia ansiosa. Mesmo se cada uma delas possui sintomas específicos, que vamos detalhar, elas possuem em comum a "fúria do suicídio" (Ey, 1954, p. 134).

A melancolia depressiva tem como características a "inibição, o colapso da motivação, da tristeza e o abatimento" (Ey, 1954, p. 117) mas também o "pessimismo (...) os sentimentos de remorso ou de indignidade, e de hipocondria" (p. 118). Ou, ainda, "desordem" e "recusa da existência" (p. 125). A consciência melancólica vive "suspensa no vazio do passado" (p. 125). O "fundo melancólico" dessa forma pura é marcado por quatro indicadores clínicos: 1. Abulia e inibição motora (desmoronamento da vontade); 2. Inibição psíquica (lentidão das ideias, impotência, parcial ou total mutismo); 3. Dor moral (consciência infeliz); 4. Pessimismo (culpa moral, indignidade, necessidade interna de desgraça) (pp. 126-13).

528 A melancolia ansiosa tem como especificidade a predominância da "perplexidade e da agitação ansiosa" (p. 117). A consciência melancólica encontra-se "aberta sobre o presente e o futuro como uma cratera escancarada" (p. 125). Esta segunda forma de melancolia pura é então marcada pela agitação, a esterilidade trágica, a perplexidade ansiosa e o pessimismo" (p. 134).

Além desses dois "tipos fundamentais" melancólicos, Ey distingue três formas atípicas (sintomáticas, evolutivas e etiológicas). Os quadros atípicos sintomáticos são constituídos de formas menores (depressão leve, estados depressivos reacionais) ou graves (melancolias delirantes, melancolias confuso-estuporosas). As melancolias delirantes constituem o quadro clínico do presente artigo, onde nos limitaremos à sua descrição. Ey discerne seis temas delirantes que, diz ele, "exprimem todos o 'delírio de pequeneza"” (Ey, 1954, p. 178):

a) O complexo de autodepreciação moral (ideias de culpa);

b) O complexo de frustração (ideais de decadência e luto);

c) O complexo de depreciação somática (ideias hipocondríacas de transformação e de negação corporais);

d) O complexo de depreciação psíquica e de despersonalização (ideias de influência, dominação e possessão);

e) O complexo de auto e heteroagressividade (ideias de perseguição);

f) O tema do nada (ideias de negação). (Ey, 1954, pp. 178-179) 


\begin{abstract}
ARTIGOS
Tais temas delirantes, por mais discretos que sejam, devem ser salientados no momento atual da degradação semiológica e biológica da nosografia contemporânea. Por conta da clínica medicamentosa e comportamental, patentes nas diferentes edições do DSM, a nosografia tende à empobrecer-se e à distanciar-se da preciosa e "bela herança" (Lacan, 1967) da psiquiatria clínica. A psicose melancólica encontra-se hoje reduzida à categoria dita dos transtornos de humor. Porém, os limites dessa categoria são tão imprecisos que essa entidade clínica revela-se tanto nebulosa quanto tentacular. Segundo essa abordagem, a causalidade subjetiva é foracluída, para o benefício da causa orgânica e a problemática da culpa, que mesmo preeminente na psicose melancólica, é evacuada (Soler, 1991, p.33). A clínica psicanalítica, em suas diferentes orientações, nunca deixou de questionar a culpa insuportável que o sujeito melancólico ressente indefinidamente (Fédida, 1974; Lambotte, 2012; Chabert \& Louët, 2013). Dessa culpa da qual o melancólico se auto-acusa, ele não pode restituir qualquer saber. Tal culpa não é, como no caso de sujeitos neuróticos, sustentada por um sentimento de culpabilidade inconsciente, pela dupla culpa que palpita no complexo de Édipo (desejo de morte do pai e de relação incestuosa com a mãe). Devemos ao inventor da psicanálise, e em seguida a Lacan, o questionamento sobre do que é feito o fundo da autoacusação na psicose melancólica.
\end{abstract}

\title{
Castigar seu ser de gozo
}

Em 1915, quando Freud compara a melancolia ao processo do luto, ele caracteriza a clínica da melancolia a partir da aversão do doente diante do seu próprio eu; os fenômenos de autocensura e depreciação são testemunhos. Uma tal ruptura da função narcísica resultaria de uma reversão da libido sobre o eu do sujeito após o desaparecimento do objeto de amor. Subtraída da consciência, tal perda revela-se elusiva e absorve o sujeito dolorosamente. Identificado ao objeto narcísico perdido, o sujeito melancólico chega a se endereçar às censuras, por conta da reversão do conflito ambivalente. Suas tendências sádicas e de ódio sofreram um retorno sobre a pessoa própria e, por isso, o melancólico seria propulsado na órbita da pulsão de morte (Freud, 1915/1968).

Em 1963, Lacan questiona a hipótese freudiana, ao precisar que o melancólico não se identifica com o objeto do desejo, mas com o objeto real da pulsão, o objeto $a$ (Lacan, 1962-1963/2004, p. 388). As autoacusações 
melancólicas não concernem à imagem especular, mas situam-se no campo da representação. Assim, elas identificam, sem titubear, o sujeito ao dejeto do simbólico. É importante distinguir o afeto depressivo, como paixão do narcisismo, do desêtre, e isso ao questionar a relação do sujeito ao gozo; ali onde a libido, no mais além do princípio do prazer freudiano, é indissociável da morte.

Assim, ao se autodifamarem, os melancólicos se realizam como resto da linguagem num frenesi inquisitório e autodenunciador que os empurra à destruição. Orientando-se por um postulado de culpabilidade - e não de inocência, como os paranoicos - suas quedas são trabalhadas, segundo suas interpretações, para o bem da humanidade, em redenção da infâmia, para que desta última a humanidade seja libertada. Tal como a paciente desesperada de Séglas que, apesar de aterrorizada diante dos castigos que ela considerava merecer, se resignava a aguentá-los, chegando até a pedi-los para, na morte, expiar sua culpa.

Ela acredita-se miserável, ladra, culpada de todos os crimes. Ela fala com terror dos suplícios que a farão sofrer (...) Eles serão horrendos. Ainda assim, ela os aguarda. Por que não acabar logo com tudo, já que ela está fatalmente condenada? Se nos aproximamos dela, ela pede que isso termine, pergunta se não vamos cortar sua garganta. Apenas nessa expiação, que ela aguarda constantemente, ela espera encontrar enfim o descanso. Em que nos serve, prolongar seu suplício? Melhor terminar logo, já que ela está pronta para ser executada... (Séglas, 1895, p. 306; tradução livre)

No ápice de sua culpabilidade delirante, o melancólico é constantemente levado a castigar seu ser de gozo por meio de diversas condutas automutiladoras. Ele também pode ser conduzido a tratar radicalmente a abjeção que sente personificar por autólise. As observações tiradas da psiquiatria clássica nos oferecem inúmeros exemplos desse tipo de passagem ao ato que, embora não sejam específicos dos sujeitos melancólicos, são bastante frequentes nessa clínica. Em particular, a paciente de Leuret que, convencida de estar condenada por conta de seus pecados, tentava de todas as maneiras possíveis e inimagináveis se suicidar até que conseguiu, ao abrir com uma lâmina de ferro o topo da cabeça, rasgando-a da testa à nuca. Após ter aberto um buraco, ela inseriu a lâmina no seu crânio. (Leuret, 1834, 2007, pp. 242-243). As passagens ao ato autoagressivas são extremamente frequentes na psicose melancólica. Com a clínica vemos que os atos de violência dita infligida aos outros são também bastante comuns. Neste sentido, a lógica dos homicídios altruístas, melancólicos ou melancoliformes, é famosa. Antes de se suicidar, 


\section{ARTIGOS}

o sujeito suprime seus próximos ou familiares para livrá-los da culpa com a qual ele estima os terem corrompido e/ou a fim de poupá-los do anúncio da suas imoralidades e maus atos, da vergonha e da desonra (Clérambault, 1921/ 1998; Trichet, Dupont, 2011).

Outras passagens ao ato, mais constantes, são menos estudadas e mesmo que não específicas aos melancólicos merecem comentários, a fim de colocar em evidência a lógica que as caracteriza. Sentindo-se abjetos e prejudiciais, é de fato frequente que os melancólicos se abandonem a atitudes violentas sobre pessoas desconhecidas. Assim, eles pretendem provar ao mundo e a eles próprios sua indignidade e a perversão da qual se acusam, tal como a paciente de Falret e de Cotard que mordia, arranhava e batia nas pessoas que se encontravam à sua volta. "Esses atos de verdade", como ela os nomeava, eram uma maneira de demonstrar a todos sua infâmia (Cotard, 1880, 1997a, p. 20; tradução livre). Quando a culpabilidade atinge seu ponto mais alto e o melancólico encontra-se face a um impasse para identificar a causa e tratá-la por meios autopunitivos, o sujeito pode mostrar-se agressivo com qualquer um que ele pense ter saído do mesmo lugar de onde ele se difama. Por um lado, para que a culpa indefinível que o invade seja identificável a partir de seus atos de violência hetero-infligidas. Por outro, para que um outro, em retorno, violente-o em sua indignidade. Essa modalidade, sobre o qual o sujeito se apoia, é uma forma de fazer funcionar a maldade do Outro, que, na melancolia, é um mal necessário quando nada mais é capaz de limitar a culpabilidade delirante. Trata-se, dentro da perspectiva diferencial, de uma distinção fundamental entre melancolia e paranoia. De fato, no caso do delírio de perseguição, ressalta Lacan

as ideias delirantes de perseguição possuem alcance de temor centrífugo e sentido de autoacusação que pode ser reconhecido nos delírios da melancolia. Mas [na paranoia] elas sempre conservam o alcance de ameaças projetadas no futuro, embora mais ou menos marcadas de iminência=... (Lacan, 1932/1975, p. 273)

Porém, na paranoia, o Outro toma a iniciativa de maltratar e ameaçar o sujeito. Já na melancolia o sujeito pode, em certos casos, tomar a iniciativa de apelar para a maldade do Outro para que este o maltrate e o condene. Ao contrário do delírio de perseguição, nos quais as ameaças são "sempre projetadas em direção ao futuro" no "sentido principalmente demonstrativo" e "de caráter ineficaz" (Lacan, 1932/1975, pp. 273-275), os delírios melancólicos simples edificam-se sobre um erro situado no passado, por vezes recente, do sujeito e do qual a eficiência é clinicamente tangível. 


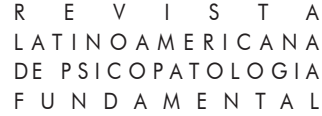

Nesse sentido, Ey observava que na melancolia simples, a "consciência melancólica" é "fechada em torno do passado, escrava de sua lembrança, contraída e dobrada sob seu peso" (Ey, 1954, p. 118). No entanto, o melancólico ansioso, que se junta ao perseguido descrito por Lacan (1932/1975), "tendo projetado fora de si mesmo a desgraça, aguarda sempre, sem trégua nem misericórdia a inquietante e inexorável ameaça" (Ey, 1954, p. 134). Aqui, diferentemente do perseguido, o melancólico ansioso vive com o medo de uma catástrofe ou ameaça iminente da qual ele não pode escapar, por conta de sua infâmia.

A identificação do responsável, o Outro para o paranoico inocente e o próprio sujeito para o melancólico, constitui uma segunda distinção essencial congruente com a clínica diferencial operada por Maleval entre os delírios melancólicos e os delírios crônicos, dentro dos quais se situam os delírios paranoicos (Maleval, 2002, p. 2).

Sendo o Outro idealizado na psicose melancólica, a maldade é marcada pela clemência já que ela constitui uma generosidade que castiga a culpa pela qual o sujeito se sente, com convicção, responsável. Na falta da culpa, o sujeito pode encontrar-se diante de um deixar cair: ele é largado por um Outro massivamente repelido pelo objeto dejeto que ele encarna.

Evidentemente, a maldade do Outro pode revelar-se saudável na melancolia, porém essa solução para tratar a indignidade radicaliza a posição de objeto do sujeito. Se alguns conseguem, ao consentir a esta última, magnificar sua melancolia (Hamon, 2014a), outros, ao optarem por tal saída, são habitualmente confrontados ao pior. De maneira que se resignam a encarnar o objeto do Outro gozador, a fazerem-se objeto da violência do Outro. De tal maneira que essas autopunições — que passam pelo outro, ao agredi-lo para fazer-se de justa vítima - não são necessariamente destinadas a salvar o sujeito melancólico de uma inevitável decadência objetal. Se elas servem para tratar sua indignidade, também alimentam, pelo mesmo movimento, a falha moral a partir da qual o sujeito se condena. De fato, a lógica infernal dessas autopunições que passam pelo outro deve ser ressaltada. Se por um lado o sujeito pretende expiar a infâmia da qual ele se autoacusa, ele alimenta, ao mesmo tempo, o gozo maligno a partir do qual se condena. A este gozo ele dá corpo, quando se mostra, na sua violência, malicioso. Razão, inclusive, pela qual nesses atos de violência o retorno é importante. Graças ao retorno, o melancólico pede para ser castigado e os atos podem ser interpretados como a prova de um erro, possibilitando mais condenação.

Esse tipo de autopunição possui, ainda assim, a função de fazer consistir a falha moral no mesmo patamar que a autodenúncia melancólica. 


\section{ARTIGOS}

A partir deste ponto de vista, a autopunição melancólica se diferencia das que encontramos em sujeitos neuróticos ou alguns paranoicos. Ao retomar a obra de Hesnard (1930/2001), Lacan desenvolve em sua tese de medicina uma abordagem inovadora da passagem ao ato paranoico. Ele considera que Aimée se autopune ela mesma ao agredir a célebre cantora da época Colette Ex-Duflot. Aimée busca inconscientemente se agredir através da cantora, que ocupa para ela uma posição de ideal do eu. Assim, o caso Aimée constitui para Lacan o protótipo da paranoia de autopunição (Lacan, 1932/1975, p. 265).

\section{Dar consistência ao crime: a autodenúncia melancólica}

Do ponto de vista do ato, a autodenúncia delirante - denunciar-se às autoridades judiciárias e administrativas como sendo o autor de um delito ou de um crime - comporta, segundo Régis, quatro versões: o sujeito se acusa de um crime inexistente; de um crime real mas que, claramente, ele não poderia ter cometido; de um crime real que ele poderia realmente ter cometido; de um crime real, que ele de fato cometeu, mas que agrava ou exagera. Mesmo se a autodenúncia se encontra presente em outras clínicas, Régis insiste que ela constitui uma particularidade médico-legal na melancolia, e que todas as versões de autodenúncia enumeradas acima fazem parte da melancolia. Ele acrescenta que

independentemente do caso, o mecanismo desta autodenúncia, do melancólico, deriva de sua tendência fundamental, característica, a ideia mórbida da culpabilidade, da autoacusação. O melancólico considera-se um miserável, como um ser indigno, capaz de tudo; se um crime é cometido, ele deve ser o autor, assim como deve ser o autor de tudo o que acontece e que acontecerá de mal em sua família ou até na humanidade: é sob a influência dessas ideias que ele se denunciará. (Régis, 1923, pp. 1100-1101; tradução livre)

Vallon propõe, para apoiar este ponto, o caso de uma mulher de 21 anos. Essa empregada doméstica se denunciou como culpada de infanticídio no dia 30 de abril de 1897, na delegacia de polícia. Ela pretende ter dado à luz clandestinamente, ter matado seu bebê por sufocamento na noite do dia 19 de abril, e de tê-lo enterrado: primeiro no jardim da casa de seus patrões e, em seguida, em um local que ela se recusa a revelar. Seu testemunho é levado suficientemente a sério para que ela seja presa. Uma investigação é aberta mas nenhuma pista sobre o primeiro enterro é encontrada. Interrogada, 


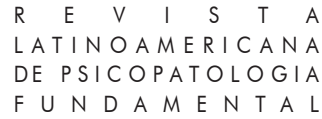

ela modifica suas declarações e aceita mostrar o local onde teria finalmente enterrado o bebê. $O$ terreno não comporta nenhum traço de enterro mas buscas são mesmo assim executadas, sem resultados. A mulher passa por um exame médico onde uma gravidez e um parto são refutados (Vallon, 1898, pp. 181-183). Vallon procede em seguida à realização de um exame de seu estado mental. Ele a considera "uma meio-imbecil" fazendo-se passar por uma mistificadora: o exame torna-se rapidamente um interrogatório onde ele refuta a totalidade de seus dizeres para fazer com que ela confesse suas mentiras. Inquisidor, ele não hesita em formular-lhe assim suas ideias ao lhe "dizer que o médico que a examinou constatou nela ausência de qualquer sinal de parto e que, consequentemente, ela mente quando diz que deu à luz a uma criança". Desconcertada, ela confessa: "Eu fui me denunciar porque havia agido mal e merecia uma punição" (Vallon, 1898, p. 185; tradução livre). Vallon tenta descobrir o que ela teria feito de mal. Ela permanece perplexa e em seguida confessa ter enterrado o bebê de outra mulher. Ele a pressiona para que ela forneça mais informações sobre a mãe dessa criança. Consciente de forçá-la a inventar respostas no decorrer de suas perguntas, ele acaba por considerar que ela é uma pessoa vaidosa que pretende chamar atenção, como qualquer 534 débil intelectual (Vallon, 1898, pp. 186-187). Essas serão as conclusões de seu relatório sobre essa mulher, que será em seguida internada em Villejuif.

Desconhecemos a razão pela qual sua autoacusação comporta um crime e/ou o enterro de uma criança. No entanto, podemos supor que a autoacusação sirva para dar corpo e sentido ao seu sentimento de culpabilidade pelo qual, ela insiste, acredita merecer punição. Sua autodenúncia junto às autoridades judiciárias tem por função uma tentativa de gravura, ao fixar a falha que a oprime. Se julgada, ela pode obter não apenas um veredito que a designa culpada, mas também uma pena repressiva que lhe permite tratar, através do aprisionamento, o gozo fora-da-lei que, no campo do Outro, a incrimina e condena. Assim, convém ressaltar que ele parece estar há bastante tempo em busca de uma sanção penal, pois esta não é sua primeira condenação e aprisionamento. Vallon descobre que a partir de 1892 ela foi condenada onze vezes por fraude, insulto à ordem, vagabundagem, mendicância e ficou presa por roubo durante seis meses em Saint-Lazare, de onde foi liberada no dia 7 de abril de 1897. Ou seja, três semanas antes de se autoacusar de infanticídio (Vallon, 1898, p. 184). Provavelmente ela encontra abrigo na detenção, mas tendo em conta a punição que pede, ela parece principalmente tentar dar consistência à sua falha através de diferentes delitos, a fim de obter uma pena que possa expiar. 


\section{ARTIGOS}

$\mathrm{Na}$ clínica da melancolia, é frequente encontrarmos sujeitos incapazes de restituir qualquer conhecimento sobre a falha da qual se acusam e, por não conseguirem nomeá-la, podem tentar dar-lhe corpo cometendo um delito ou se denunciando como responsáveis de um crime que não cometeram, mas pelo qual se sentem responsáveis. Assim, Dupré, em 1902, considera que

a evolução do delírio melancólico de autoacusação na sua fase médico-legal pode ser resumida nos termos da seguinte filiação cronológica: $1^{\circ}$ estado melancólico, $2^{\circ}$ delírio de culpabilidade difusa, $3^{\circ}$ autoacusação precisa, $4^{\circ}$ autodenúncia ativa" [acrescentando que] "quase todos os melancólicos chegam ao segundo estado; muitos atingem o terceiro; uma minoria ínfima alcança o quarto termo. Somente estes últimos são os autoacusadores médico-legais. (p. 800; tradução livre)

Dupré interessa-se principalmente pela questão da penalidade incorrida pelo autoacusador em resposta à sua falsa declaração às autoridades. Ele explicita de maneira insuficiente a lógica que sustenta o delírio melancólico. O sujeito, na tentativa de rigor de seu delírio, tenta de fato circunscrever a falha que, difusa, o oprime, elaborando então uma sentença que condena seu ser de gozo; e isso para assegurar-se do tratamento por autopunição. Porque se ele inventa uma espécie de julgamento que, ao designá-lo como culpado, fixa a falha que lhe incrimina, fá-lo para comutar a culpa em uma pena que possa ser expiada; pelo menos da maneira que ensinam os casos seguintes, a fim de sempre sofrer.

Mesmo quando não sustentada por um comando alucinatório ao qual o sujeito se submete, a autodenúncia na melancolia funciona de maneira similar, embora o processo se revele mais limitado. O sujeito possui como única possibilidade para castigar sua infâmia, resignar-se a encarnar a figura monstruosa do criminoso mesmo se isso implica cometer o assassinato, para dar credibilidade ao personagem e alimentar a vontade de sofrer sua indignidade, às vezes até a morte. ${ }^{1}$ Aliás, essa solução para tratar o gozo deletério do qual o sujeito se acusa mostra-se factícia e pouco elaborada. Não somente ele se condena a partir do crime de um outro, ou então comete alguns pequenos furtos para provar que é culpado, mas as infrações a partir das quais ele tenta dar forma e consistência à sua falha permanecem, por assim dizer, elementos de conviç̧ão inconsistentes. Por isso, uma vez a culpabilidade pacificada pelo recurso à lei, alguns retificam suas confissões, ao clamarem inocência

\footnotetext{
${ }^{1}$ Como nos casos de suicídio indireto.
} 


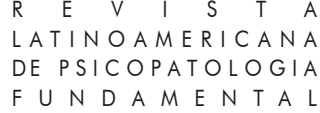

ou assumirem que mentiram. Completamente diferente são as invenções sob medida daqueles que, ao mobilizarem o significante, se resignam, em seus delírios tristes, a sofrer a dor de existir ou então se destinam a aturar, por conta do julgamento de suas indignidades, uma pena ad vitam aeternam.

\section{Pura dor de existir, indignidade proclamada e pena propiciatória}

O caso de Marc nos parece demonstrativo da lógica autoterapêutica pela qual um sujeito melancólico inventa uma autopunição radical, tão determinada e dolorosa quanto definitiva, a fim de tratar o gozo deletério do qual ele é objeto; e castigar a falha que, segundo sua interpretação, é a causa deste gozo.

Marc, como descrito pelos autores (Trichet et al., 2015), tem por volta de sessenta anos. Ele é morador de rua há quase duas décadas. O encontro com ele deu-se num contexto de emergência subjetiva num local de consulta. Ele apresentou-se, segundo sua expressão, "sob anonimato" insistindo sobre o fato de não possuir "nome, pátria ou família" (Trichet et al., 2015, p. 334). Atormentado, temendo ser um criminoso, ele revisitava sem parar um elemento de seu passado: ele teria sido acompanhado por uma assistente social que se tornou rapidamente invasiva. Felizmente, ela saiu de cena quando Marc lhe implorou para deixá-lo sozinho. Ele poderia tê-la esfaqueado, tanto ela se mostrou insistente para fazer com que ele se beneficiasse de um alojamento numa instituição social. Ela inclusive disse a Marc que ele poderia, com a participação nesse programa, recuperar sua situação financeira (p. 334). Porém, tal desfecho extremo tem como função principal castigar, e ao mesmo tempo limitar sua culpabilidade delirante. Esta lhe permite se proteger de ser "um canalha" (p. 335; tradução livre). Marc considera que o dinheiro contribuiu para que ele se tornasse um "monstro de orgulho", quando era um jovem adulto. Ele tinha certeza, na época, de ter-se aproveitado de todo mundo e assim, de ter "cometido o pior" para com a humanidade (Trichet et al., 2015, p. 335). Desde então, evita todo e qualquer contato humano e leva uma existência das mais miseráveis, sobrevivendo de restos para radicalmente limitar a malícia da qual se autoacusa. Quando a assistente social lhe propõe melhorar, recuperar sua situação financeira, sua condição existencial, ela coloca em perigo a solução com a qual Marc se orienta para conjurar sua infâmia. Razão pela qual, nesse contexto de invasão, ele poderia ter passado ao ato a fim de se defender de ser "um canalha", como ele se representa sem mais. 


\section{ARTIGOS}

Marc foi visto apenas seis vezes. Certificado de que não é um criminoso, ele coloca término às sessões quando surge a questão de uma internação. Provavelmente ele voltou a abrigar-se num local onde para a vida não há moradia. De fato, Marc elege domicílio num universo desprovido de humanidade, dentro do qual ele aguenta e sofre eternamente sua falha moral, a fim de purgá-la. Acreditando-se já morto, ele considerava que "não era mais desse mundo"; a menos que vivesse, justamente, "em uma casa com as sombras", "lá onde sempre morrem os canalhas" (Trichet \& al., 2015, pp. 335-336; tradução livre).

Assim, sua melancolia toma ares da síndrome de Cotard (Cotard, 1882/1997b). Nesse delírio de negação que se desenvolve sobre fundo de culpabilidade delirante e muitas vezes ideias de danação, tudo aquilo que o sujeito pensa possuir de corrupto ou tudo que pensa ter estragado com sua presença infame mostra-se por sua falha suprimido, morto, erradicado. Se ele parece negar a existência daquilo que perdura, afirma a pura verdade; aquela que, sensivelmente, se lhe impõe com flagrância. Assim ele não possui mais corpo, órgãos, família, inteligência, alma; tudo foi abolido, destruído, nada mais existe (mundo, tempo, moral, Deus etc.). Quando as negações se universalizam, ele pode sentir-se imortal; mas mesmo nessa forma megalomaníaca, a síndrome de Cotard permanece um delírio triste: "os doentes, insiste Séglas, são imortais apenas para suportar eternamente seus males" (Séglas, 1894/ 1997, p. 186; tradução livre). Não sendo mais nada, eles não são nem mortos, nem vivos, mas dedicados infatigáveis a uma agonia sem fim que consideram como destino merecido. Acusando sua infâmia de ser a causa, eles proferem que foram justamente atirados para o meio dos mortos eternos, esquecidos. Assim condenados a uma morte perpétua, eles não podem descrever esse universo desesperado e desumanizado feito, em seu espaço, de atemporalidade e de infinidade. Tais sujeitos levam uma existência indefinível fora do mundo. Nesta zona de "entre-duas-mortes" (Lacan 1959-1960/1986; tradução livre), eles erram em um mundo desertado de toda alteridade, onde a potência significante se extinguiu. Nessa sobrevivência dolorosa, a vida nada mais é do que morte e não tem mais sentido, é pura dor de existir. O Outro não funciona mais como apoio, e o sujeito, na mais extrema desordem, encontra a desaparição de todo desejo; a pura dor, aquela de não lhe faltar nada, a não ser uma falta. É por isso que alguns podem chegar a implorar que os matemos, que criemos uma falta capaz de lhes privar de vida ou então passar ao ato afim de inscrever um corte significante - caso das automutilações - ou, mais frequentemente, visar precisamente a perda por autólise. 


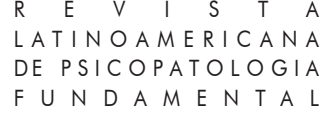

Marc resolveu consentir viver nesta zona "entre-duas-mortes" na qual seu destino é, enquanto canalha, morrer para sempre, a fim de sofrer inexoravelmente o crime de sua infâmia. Sobre fundo de autopunição e de severos interditos existenciais, ele trata assim sua culpabilidade delirante. Tal solução subjetiva o conduziu certamente ao pior, por conta de sua radicalidade, porém com o beneficio paradoxal de uma forma de estabilização. A solução que Marc inventou para remediar sua indignidade melancólica o levou a assumir uma vida de castigos, sob os auspícios de um Outro malvado. Obviamente, o autotratamento da psicose declarada opera a partir de uma forma fundamental de derrelicção na qual e pela qual ele visa o sacrifício do ser de dejeto. Mas essa tentativa de rigor ultrapassa a pobreza dos delírios melancólicos que, em suas formas estuporosas, ansiosas e paranoides, continuam centradas sobre a repetição de uma falha inqualificável vivida como insuportável. Tal falha comporta um peso que convoca o sujeito diante da exigência de um sacrifício à altura de sua amplitude ilimitada: sua morte e também a morte, por vezes, de seus familiares, para libertá-los da falha moral a partir da qual, segundo sua interpretação, ele os corrompeu ou condenou. Se Marc pensou em suicidar-se é porque considerava tal ato "uma saída honrada"; ele acrescenta que "não 538 a merece" e que deve "pagar pelos seus crimes". Sua situação subjetiva de exclusão social e de miséria extrema constitui para ele a pena apropriada. Antes de elaborá-la e de colocá-la em execução, ele chegou a pensar em "se entregar à polícia" ou "à justiça" para "fazer trabalhos forçados" ou "ser linchado" (Trichet \& al., 2015, p. 335; tradução livre).

Quando se entregam às forças da lei, alguns melancólicos se resignam assim a sofrer a culpa inqualificável que os oprime. Ao pressentirem que esta falha moral pode ser bem ouvida no tribunal do Outro, eles podem ser empurrados a materializá-la, passando ao ato, cometendo delitos ou crimes. Com esse objetivo, e para serem castigados até que a morte chegue, dependendo das épocas e das latitudes, outros não hesitam a passar pela justiça penal para dispor de um juiz que pode, ao inscrever o erro, responder à culpabilidade delirante. Já Marc decidiu atingir seu objetivo ao estipular, em seu delírio, o ato de sua acusação por abjeção. Ao inventar esta sentença, ele fixou a falha que o condena a sofrer, para purgá-la, a pena de sua infâmia. Tal solução sob medida se organiza sobre o fundo do delírio triste, e não tem outros fins que consumam sua própria perda a partir da pena que ele se inflige. Esta última, no entanto, revela-se saudável já que ela permite a Marc tratar, através de severas regras e limitações existenciais coercitivas e punitivas, o gozo maligno do qual ele tem a certeza de ser a encarnação. 


\section{ARTIGOS}

\section{Melancolia, autopunição e autoterapia}

A clínica proposta aqui como contribuição nos ensina que o sujeito melancólico pode tentar tratar sua culpabilidade delirante pela violência autoinfligida, pela violência feita ao outro ou por meio de delitos e crimes. Ele tenta, assim, dar consistência, às vezes tentando realizá-la no real, à falha que o incrimina no campo simbólico a fim de castigá-la. Mas essas buscas de pacificações do gozo radicalizam sua identificação ao objeto $a$, ao alimentar a falha a partir da qual ele se condena. No entanto, em sua lógica dupla, a dualidade autoacusação-autopunição permite um modo de equilíbrio do gozo. Claro, às vezes ao preço, como no caso de Marc, de uma fundamental mas salvadora decadência objetal. Mas a clínica também nos ensina que uma estabilização pode surgir em favor de uma conduta de autopunição moderada através da qual o sujeito pacifica a longo prazo sua culpabilidade delirante ao tratar o gozo do qual ele se autoacusa. De fato, há sujeitos que testemunham terem encontrado uma forma de estabilização cotidiana a partir de tarefas ingratas que executam, às vezes até delas fazerem profissão, a fim de tratar, com tais medidas punitivas, a culpabilidade delirante (Hamon, 2014a; Hamon, 2014b; Hamon \& Gaspard, 2016). Eles também ensinam que a pura dor de existir dos sujeitos melancólicos pode se transformar em pena autoterapêutica, na organização de uma autopunição moderada a partir da qual eles podem assim encontrar, ao fazer dela sua causa, um modo de inscrição no laço social, além de um limite à sua evicção da cena do mundo. Nesse sentido, a pena na melancolia mostra-se, na ambivalência, capital. Onipresente, ela é tão radical quanto crucial. O tratamento de um melancólico, dada sua lógica, consiste muitas vezes em fazer limite. Já em certos casos, o caminho é outro: circunscrevendo e fixando a falha, trata-se de sustentar a elaboração e a criação de uma pena sob medida e regrada, que não implique a desaparição do sujeito.

\section{Referências}

Chabert, C., \& Louët E. (2013). Troubles bipolaires et manie-mélancolie: continuité ou rupture? Psychologie clinique et projective, 19, 11-54.

Clérambault, G.-G. de (1998). L'homicide altruiste chez les mélancoliques. In Euvres psychiatriques (pp. 668-678). Paris, France: Frénésie. (Trabalho original publicado em 1921). 


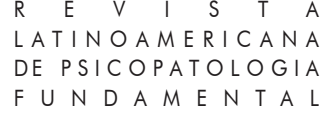

Cotard, J. (1997a). Du délire hypocondriaque dans une forme grave de mélancolie anxieuse. In J. Cotard, M. Camuset, \& J. Séglas. Du délire des négations aux idées d'énormité (pp. 19-25). Paris, France: L'Harmattan. (Trabalho original publicado em 1880).

Cotard, J. (1997b). Du délire des négations. In J. Cotard, M. Camuset, \& J. Séglas. Du délire des négations aux idées d'énormité (pp. 25-53). Paris, France: L'Harmattan. (Trabalho original publicado em 1882).

Dupré, E. (1902). Les auto-accusateurs au point de vue médico-légal. Revue neurologique, 10, 798-806.

Ey, H. (1954). Mélancolie (étude n. 22). In H. Ey, Études psychiatriques, 3 (pp. $117-$ -200). Paris, France: Désclée de Brouwer

Fédida, P. (1974). Dépression et mélancolie: remarques concernant les fondements d'une psycho-pathologie. Bulletin de psychologie, 317, 678-683.

Freud, S. (1968). Deuil et mélancolie. In Métapsychologie (pp. 145-171). Paris, France: Gallimard. (Trabalho original publicado em 1915).

Freud, S. (2001). Le moi et le ça. In Essais de psychanalyse (pp. 177-234). Paris, France: Payot. (Trabalho original publicado em 1923).

Hamon, R. (2014a). Le Padre Pio, une mélancolie magnifiée par la religion catholique. Cliniques méditerranéennes, 89, 257-270.

Hamon, R. (2014b). Marques corporelles: souffrance d'être et prévalence du regard. In J. L. Gaspard (dir), La souffrance de l'être (pp. 203-217). Toulouse, France: Eres.

Hamon, R., \& Gaspard, J.-L. (2016). Douleur d'exister, mélancolie magnifiée et lien social. FiLUM, 4, à paraître.

Hesnard, A. (2001). Les processus d'auto-punition. Paris, France: L'Harmattan. (Trabalho original publicado em 1930).

Lacan, J. (1966). Kant avec Sade. In Ecrits (pp. 765-790). Paris, France: Seuil. (Trabalho original publicado em 1963).

Lacan, J. (1967). Petit discours aux psychiatres. Cercle psychiatrique Henri Hey, conférence prononcée à Sainte-Anne, 10 novembre 1967, conférence inédite.

Lacan, J. (1975). De la psychose paranoïaque dans ses rapports avec la personnalité. Paris, France: Seuil. (Trabalho original publicado em 1932).

Lacan, J. (1986). Le séminaire. Livre VII. L'éthique de la psychanalyse. Paris, France: Seuil. (Trabalho original publicado em 1959-1960).

Lacan, J. (2001). Télévision. In Autres écrits (pp. 509-545). Paris, France: Seuil. (Trabalho original publicado em 1974).

Lacan, J. (2004). Le séminaire. Livre X. L'angoisse. Paris, France: Seuil. (Trabalho original publicado em 1961-1963). 


\section{ARTIGOS}

Lambotte, M.-C. (2012). Le discours mélancolique. De la phénoménologie à la métapsychologie. Toulouse, France: Erès.

Leuret, F. (2007). Fragments psychologiques sur la folie. Paris, France: FrisonRoche. (Trabalho original publicado em 1834).

Maleval, J-C. (2002). Logique du délire. Paris, France: Masson.

Régis, E. (1923). Précis de psychiatrie. Paris, France: Doin.

Séglas, J. (1997). Le délire des négations dans la mélancolie. In J. Cotard, M. Camuset, \& J. Séglas. Du délire des négations aux idées d'énormité (pp. 179-208). Paris, France: L'Harmattan. (Trabalho original publicado em 1894).

Séglas, J. (1895). Leçons cliniques sur les maladies mentales et nerveuses. Paris, France: Asselin et Houzeau.

Soler, C. (1991). Estudios sobre las psicoses. Buenos Aires, Argentina: Manantial.

Trichet, Y., \& Dupont, A-S. (2011). Logique des homicides dits altruistes. Clinique de l'infanticide. Bulletin de psychologie, 514, 347-357.

Trichet, Y., Hamon, R., \& Gaspard, J-L. (2015). Traitement psychanalytique et subjectivation de l'acte d'homicide chez des sujets psychotiques. Bulletin de psychologie, 538, 331-339.

Vallon, C. (1898). Aliénée auto-accusatrice. Annales d'hygiène publique et de médecine légale, 39, 179-189.

\section{Resumos}

(When punishmet is a necessary evil within melancholic psychosis)

This paper questions self-therapeutic logic within melancholic delusion. The clinical cases presented here as a contribution teach us that melancholic psychotics can try to treat their delusional blame through self-inflicted violence, and also through hetero- aggressive behavior and crime. In each of these cases, the "self-accusation-self-punishment" relationship is at work. This balances out pleasure - to the extent that we can state that punishment, within ambivalence (moral suffering and inflicted punishment), is a necessary evil in melancholia.

Key words: Melancholic psychosis, delusion, crime, self-blame, self-punishment

(La peine comme mal nécessaire dans la psychose mélancolique)

Cet article interroge la logique auto-thérapeutique du délire mélancolique. Les cas cliniques mis ici à contribution enseignent que le psychotique mélancolique peut tenter de traiter sa culpabilité délirante à partir de la violence qu'il s'inflige mais 


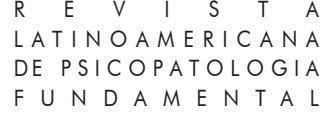

aussi à partir de conduites hétéro-agressives, de délits et de crimes. En chaque cas, le couple «autoaccusation-autopunition» est à l'œuvre. Il permet l'équilibration de la jouissance et on peut donc affirmer que la peine, dans son double sens (douleur morale et sanction appliquée) est un mal nécessaire dans la mélancolie.

Mots clés: Psychose mélancolique, délire, crime, autoaccusation, autopunition

(Cuando la pena es un mal necesario en la psicosis melancólica)

Este artículo cuestiona la lógica autoterapéutica del delirio melancólico. Los casos clínicos presentados aquí, demuestran que el psicótico melancólico puede intentar tratar su culpabilidad delirante a partir de la violencia que se aplica a sí mismo, pero también a partir de conductas heteroagresivas, de delitos y de crímenes. En cada caso, el dúo - autoacusación y autocastigo - está activo y permite equilibrar el goce. Por lo tanto, se puede postular que el dolor, en la ambivalencia (dolor moral y pena impuesta) es un mal necesario en la melancolía.

Palabras clave: Psicosis melancólica, delirio, crimen, autoacusación/ autocastigo

(Strafe/Leiden als notwendiges Übel in der melancholischen Psychose)

Dieser Artikel stellt die autotherapeutische Logik des melancholischen Wahnes in Frage. Die angeführten klinischen Beobachtungen lehren, dass der melancholische Psychotiker mit der Gewalt, die er sich selbst antut, aber auch mit seinem aggressiven Verhalten gegenüber anderen, mit Straftaten und Verbrechen versuchen kann, seine wahnsinnigen Schuldgefühle zu behandeln. In allen analysierten Fällen ist das Paar „, Selbstbeschuldigung-Selbstbestrafung “ am Werk, welches eine Regulierung des Genusses erlaubt. Man könnte also behaupten, dass das moralische Leiden und die angewandte Strafe ein notwendiges Übel der Melancholie sind.

Schlüsselwörter: Melancholische Psychose, Wahn, Verbrechen, Selbstbeschuldigung, Selbstbestrafung

Citação/Citation: Hamon, R., \& Trichet, Y. (2017,setembro). Quando a pena é um mal necessário na psicose melancólica. Revista Latinoamericana de Psicopatologia Fundamental, 20(3), 526-543. http://dx.doi.org/10.1590/1415-4714.2017v20n3p526.8

Editores do artigo/Editors: Profa. Dra. Ana Maria Rudge e Profa. Dra. Sonia Leite

Recebido/Received: 8.6.2017/ 6.8.2017 Aceito/Accepted: 15.3.2017 / 3.15.2017 


\title{
ARTIGOS
}

Copyright: (C) 2009 Associação Universitária de Pesquisa em Psicopatologia Fundamental/ University Association for Research in Fundamental Psychopathology. Este é um artigo de livre acesso, que permite uso irrestrito, distribuição e reprodução em qualquer meio, desde que o autor e a fonte sejam citados / This is an open-access article, which permits unrestricted use, distribution, and reproduction in any medium, provided the original authors and sources are credited.

Financiamento/Funding: Os autores declaram não terem sido financiados ou apoiados / The authors have no support or funding to report.

Conflito de interesses/Conflict of interest: Os autores declaram que não há conflito de interesses / The authors have no conflict of interest to declare.

\section{Romuld Hamon}

Psychanalyste; Maître de conférences en psychopathologie. EA 4050.

Université Rennes 2 Haute-Bretagne

Place Recteur le Moal

35043 Rennes Cedex, France

romuald.hamon@uhb.fr

\section{Yohan Trichet}

Psychanalyste; Maître de conférences en psychopathologie. EA 4050.

Université Rennes 2 Haute-Bretagne

Place Recteur le Moal

35043 Rennes Cedex, France

yohan.trichet@uhb.fr

\author{
Mila Signorelli (tradutora) \\ Psicóloga clínica; Mestre em Psicopatologia \\ Université Rennes 2 Haute-Bretagne. \\ E-mail: milasig@gmail.com
}

This is an open-access article, which permits unrestricted use, distribution,

(cc) BY-NC and reproduction in any medium for non-commercial purposes provided the original authors and sources are credited. 